$1-1-1984$

\title{
Fencing strategies for beef and sheep producers : a comparative cost analysis
}

Maliheh Rouhani-Iravan

Robert O. Burton

Follow this and additional works at: https://researchrepository.wvu.edu/ wv_agricultural_and_forestry_experiment_station_bulletins

\section{Digital Commons Citation}

Rouhani-Iravan, Maliheh and Burton, Robert O., "Fencing strategies for beef and sheep producers : a comparative cost analysis" (1984). West Virginia Agricultural and Forestry Experiment Station Bulletins. 688.

https://researchrepository.wvu.edu/wv_agricultural_and_forestry_experiment_station_bulletins/582 @ WVU. It has been accepted for inclusion in West Virginia Agricultural and Forestry Experiment Station Bulletins by an authorized administrator of The Research Repository @WVU. For more information, please contact ian.harmon@mail.wvu.edu. 

AND SHEEP PRODUCERS:

A COMPARATIVE COST ANALYSIS

Bulletin 688 April 1984

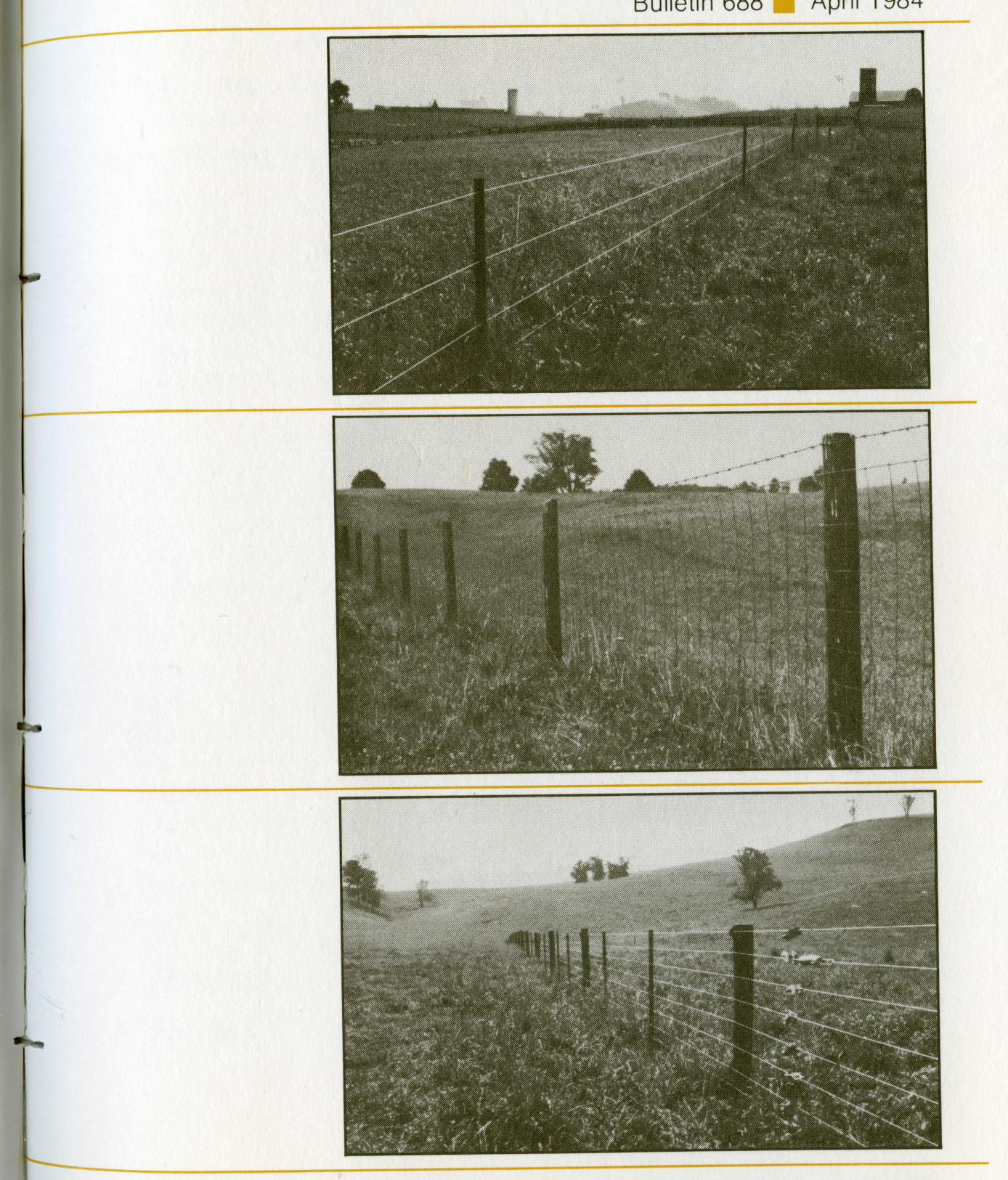

AGRICULTURAL AND FORESTRY EXPERIMENT STATION WEST VIRGINIA UNIVERSITY 


\section{Contents}

\section{Authors}

Maliheh Rouhani-Iravan is a former graduate student, and Robert O. Burton, Jr. is assistant professor, Division of Resource Management, College of Agriculture and Forestry.

\section{Acknowledgment}

Appreciation is expressed to Anwarul Hoque, Arthur W. Selders, and Mary E. Templeton for helpful comments on an earlier draft. The authors are responsible for any remaining errors.

Second Printing October 1986

\section{COVER}

Three types of fences-top, high-tensile electric; middle, woven wire; bottom, high-tensile nonelectric.

West Virginia University

Agricultural and Forestry Experiment Station

College of Agriculture and Forestry

Dale W. Zinn, Director

Morgantown

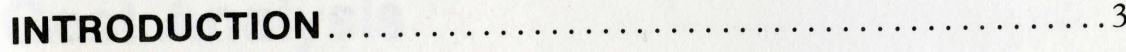

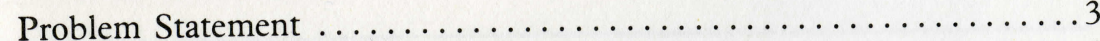

Objectives ..............................

ANALYTICAL PROCEDURES AND DATA $\ldots \ldots \ldots \ldots \ldots . \ldots$

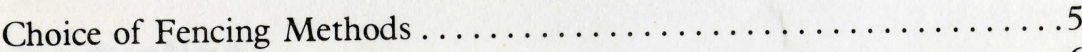

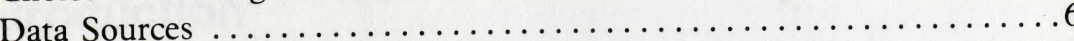

Fencing Strategies: Continuous and Rotational Grazing ...........6

Fencing Strategies: Continuous and Rotational Grazing $\ldots \ldots \ldots \ldots \ldots \ldots$

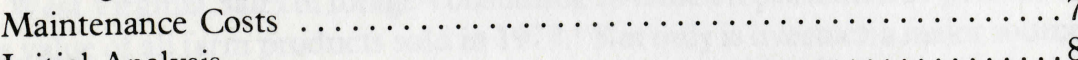

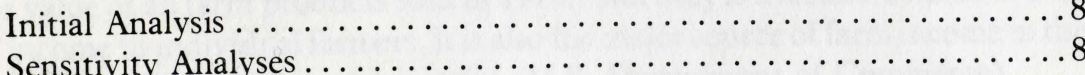

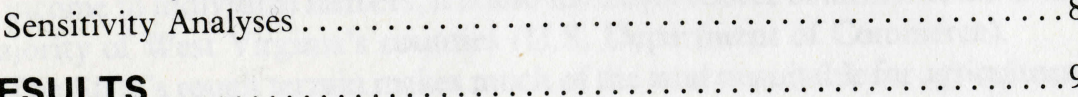

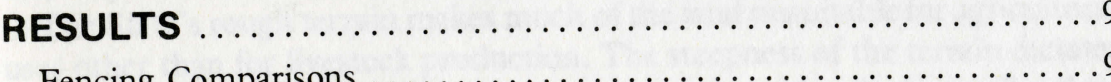

Fencing Comparisons $\ldots \ldots \ldots \ldots \ldots \ldots \ldots \ldots \ldots \ldots \ldots \ldots$
Comparisons of Three Types of

Fences when Continuous Grazing Is Used $\ldots \ldots \ldots \ldots \ldots \ldots \ldots$

Comparisons of Three Types of

Fences when Rotational Grazing Is Used ....................11

Comparisons with Results from Other Situations ...............

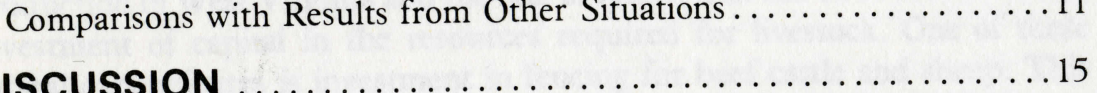

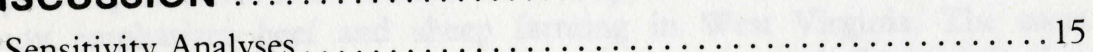

Sensitivity Analyses ........................................... 15

Capital Costs Variations . . . . . . . . . . . . . . . . . . . . . . . 16

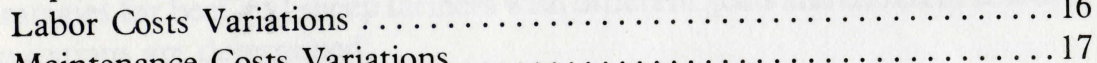

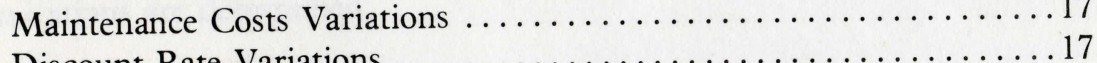

Discount Rate Variations ................................

Non Cash Inputs .................................... 19

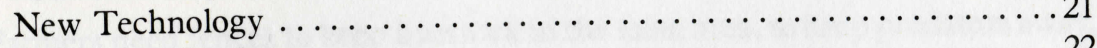

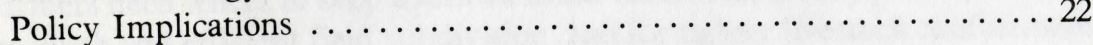

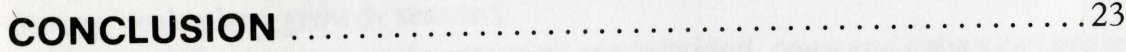

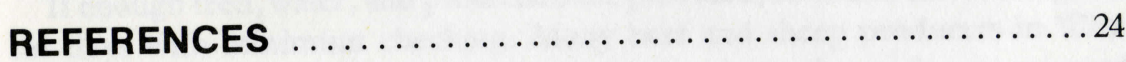

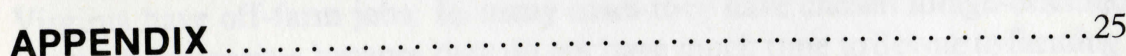




\section{Fencing Strategies for Beef and Sheep Producers: A Comparative Cost Analysis}

Maliheh Rouhani-Iravan and Robert O. Burton, Jr.

\section{Introduction}

In West Virginia, sales of forage-consuming livestock represented 29 percent of the value of all farm products sold in $1979 .{ }^{1}$ Not only is livestock a major source of income to individual farmers, it is also the major source of farm income in the majority of West Virginia's counties (U.S. Department of Commerce).

The State's rough terrain makes much of the land unsuitable for agricultural uses other than for livestock production. The steepness of the terrain dictates that much of the land be used for permanent pasture with only the small valleys and gentle slopes available for row crop production and for meadows (Barr, p. 3).

Many questions have been raised concerning the profitability of livestock production in West Virginia and the rate of return that can be realized from an investment of capital in the resources required for livestock. One of these capital expenditures is investment in fencing for beef cattle and sheep. This study emphasizes beef and sheep farming in West Virginia. The costs associated with alternative types of fencing are measured. Optimal fencing strategies for beef and sheep farmers with different goals and different resource limitations are determined.

\section{Problem Statement}

Farmers need fences to keep livestock in the farm area, to keep predators away, for quick and efficient field subdivision, and for tighter livestock confinement during peak plant growth seasons.

If enough feed, water, and protection are provided, cows and calves can graze for days with minimum checking. Many beef and sheep producers in West Virginia have off-farm jobs. In many cases they have chosen forage-oriented livestock enterprises because they do not have much time to devote to farming.

'Derived from West Virginia Agricultural Statistics, 1981. 
To meet their goal of maintaining a farm operation without using large amounts of farm labor, an efficient and effective fencing strategy is needed.

If cattle or sheep are left in an area without adequate fences, they will damage the farmer's crops as well as properties of neighbors. In grazing management, farmers might want their livestock to have access to a specific source of water, or they might need to protect the animals from dangerous areas such as cliffs. Thus, they need fences to help meet water and protection needs. In addition, if rotational grazing is used, more elaborate fencing strategies are required for greater livestock control.

In the case of sheep and sometimes calves, the problem of predators also exists. In 1978, approximately 2 percent of all breeding ewes and lambs owned by participants in the West Virginia University Allegheny Highlands Project were killed by predators. Bear and dogs were the two major predators, with bear accounting for more than 50 percent of the ewes killed (Baker, Fausett, Lewis, and Inskeep, p. 20).

Scarcity of such inputs as time and money may prevent farmers from building proper and adequate fences. Thus, the typical farmer needs to be informed about time and money requirements of different fencing strategies. Many West Virginia farmers have low incomes and are concerned about the costs associated with different types of fences. Consequently, they look for the lowest cost type of fence that can meet their needs.

The purpose of this research is to determine the most economical and efficient fencing strategies for farmers with different needs, so that they can choose the method that best suits their goals and farm resources.

\section{Objectives}

The objective of the study is to provide information that would be useful for farmers who produce livestock and need fences. Specific examples of information farmers are concerned about when choosing a fencing strategy are:

1. Materials needed in fence building.

2. Initial capital needed for investment in fence construction.

3. Expected useful life of the fence.

4. Cost of maintaining the fence in a reliable working condition.

5. Type of fence that is most efficient when there is adequate capital but limited labor available for building or maintaining the fence.

6. Type of fence that is most efficient when there is limited capital but abundant labor.

Alternative fencing strategies will be evaluated for livestock farmers who manage their farms with a continuous grazing pattern and those who use rotational grazing.

\section{Analytical Procedures and Data}

This study involves an evaluation of six different ways to meet the fencing requirements on an example livestock farm. Budgets associated with the alternative fencing strategies were prepared. Information on fencing costs, durability, and reliability was obtained from published sources, agricultural scientists, professional fence contractors, and fencing material suppliers.

Since fence construction is a long-run investment, the net present value method of capital budgeting was used to compare alternative fencing strategies. Different fences require different levels of initial capital outlay and maintenance costs during their lifetime. In this research, all these costs were determined. Maintenance costs associated with each fencing strategy over its lifetime were brought back to the initial year and added to the investment cost to obtain the present value of total costs associated with each method.

Because individual farmers may have different goals and resource limitations, budgets were organized to summarize costs associated with different categories of inputs. Alternative goals may include profit maximization, or cost minimization. Important resources which may be limited are capital and labor. Many farmers have capital limitations and prefer building a labor-intensive type of fence; others might have enough capital to spend for an adequate fence and prefer a capital-intensive type of fence. Still other farmers may be able to provide limited capital and labor but also need to determine a strategy that will best utilize their available resources. The fencing methods chosen are suitable for farmers who keep both sheep and cattle and use rotational or continuous grazing patterns.

After the budgets were prepared, sensitivity analyses were conducted to measure the sensitivity of results to changes in fencing material costs, labor costs, maintenance costs, years of useful life, and the discount rate. This analysis was done because the data were based on experts' best estimates of average materials needed for fence construction and their respective costs. In the real world a large amount of variability can be expected.

\section{Choice of Fencing Methods}

Traditionally, woven wire, barbed wire, or a combination of woven and barbed wire fences has been used to confine livestock. However, in recent years with the introduction of high-tensile fences from Australia and New Zealand, there have been arguments that these new fences are less expensive, more durable, and more effective in protecting livestock against predators than traditional fences. For example, high-tensile nonelectric wire fencing is creating considerable interest because of its longer life and lower costs than conventional 
fences (Selders, p. 1). Electric fencing has been convenient for temporary usage, but in recent years, the introduction of galvanized high-tensile wire and the development of much more powerful electric fence controllers, have enabled permanent, multi-wire electric fencing to be erected for the control of livestock. Use of such fencing is now widespread (Armstrong, Banks, and Gill)

Three types of fences are considered in this study: five-strand, high-tensile electric; ten-strand, high-tensile nonelectric; and woven wire. The idea was to choose strategies among high-tensile and conventional types of fencing. Tenstrand is a common type of high-tensile nonelectric, and five-strand a common type of high-tensile electric fencing. Woven wire is a widely used conventiona type of fencing. Furthermore, it was assumed that both cattle and sheep would graze on the same farm, so fencing strategies capable of confining both sheep and cattle were needed.

Each of the three types of fences was applied to an example farm in southern West Virginia using continuous grazing. Each type also was combined with temporary electric fencing to evaluate a rotational grazing strategy. Therefore, a total of six grazing and fencing alternatives was evaluated. There was a total of 25,115 feet of permanent fence. An additional 5,300 feet of temporary fencing was needed for rotational grazing.

\section{Data Sources}

To prepare fencing budgets, related publications were obtained from different experts and libraries of West Virginia and other states. Five persons knowledgeable about fencing - an extension agricultural engineer at West Virginia University; the manager of Willow Bend Farm in Union, West Virginia; two fence contractors, one in southern West Virginia and one in southwestern Pennsylvania; and a field man at Southern States Cooperative in Morgantown, West Virginia were visited and interviewed. Written and verba information about specifications of materials and their respective prices were obtained. This information and information from published sources was used to derive fencing specifications and fence budgets. After initial drafts of the budgets were prepared, the fencing experts were contacted for verification of the budgets and additional information about maintenance costs.

\section{Fencing Strategies: Continuous and Rotational Grazing}

For the continuous pattern of grazing, cattle and sheep are assumed to graze on a large field during the entire grazing season. ${ }^{2}$ In rotational grazing, the large pasture field is subdivided into smaller fields. This may allow the best use of available forage, since livestock grazing can be timed according to pasture growth. ${ }^{2}$ On the example farm, a small pasture field located across the road from the farmstead was also
fenced.
Grasses are most nutritious at a certain stage of growth. Nutritional quality decreases if grasses are too mature and become stemmy. By the use of rotational grazing, livestock can graze on each field when the grass is most nutritious. Besides, if cattle and sheep graze on a particular area of the pasture for too long, subsequent growth of the pasture may be hindered and soil erosion may occur. With rotational grazing, livestock can be moved to another pasture while the previously grazed pasture is recovering. It has been argued that rotational grazing may result in better pasture utilization than continuous grazing. If grazing may result in better pasture utilization than continuous grazing. If

For rotational grazing, three-strand temporary electric fencing is used for additional subdivisions in fields fenced with the same permanent fences which are used for continuous grazing.

Temporary fences are intended for use over a period of a few weeks, or possibly a few months, depending on what rotational pattern of grazing is used. After that, they will be removed and used in some other place or stored until needed.

\section{Maintenance Costs}

Alternative fences have different useful lives and maintenance costs. It is estimated that woven wire fences will last 20 years, high-tensile nonelectric fences 30 years, high-tensile electric fences 25 years, and temporary electric fences 7 years. It is further believed that the average yearly maintenance costs of woven wire fencing are about 8 percent, high-tensile nonelectric about 3 percent, high-tensile electric about 6 percent, and temporary electric fences about 11 percent of their respective total investment costs.

Temporary electric fences will be replaced as they wear out. Reinvestmen costs will be equal to the total costs of wire and related items, gates, and 60 percent of the cost of the charger. Labor costs for replacement of temporary electric fences are already accounted for in the 11 percent yearly maintenance cost.

The maintenance costs were based on information obtained from four of the persons interviewed. Two of these experts suggested high values for maintenance costs, and the other two suggested low values for it. Therefore, an average of the estimates was taken and rounded off to the nearest percentage. Annual maintenance costs over the useful lives of the fences were adjusted to Annual maintenance costs over the useful lives of the fences were
reflect the fact that fences have lower maintenance costs when they are new higher costs later.

${ }^{3}$ Attempts to obtain data about the relative productivity of rotational and continuous grazing have Attempts to obtan indicated that at in West Virginia. 


\section{Initial Analysis}

It was assumed that investment costs of fences are paid when the fences are constructed. However, maintenance costs will be incurred at different times during the useful life of the fences.

Present value calculations were used to bring maintenance costs incurred in different years of each fence's useful life, back to the first year when the original investment costs were paid. The present value of the maintenance costs was added to investment costs to obtain the total costs of each type of fence. Since different fences have different lengths of useful life, equivalent level annuities for alternative fencing strategies were calculated which represent equivalent yearly costs of each strategy, so that cost comparisons can be easily made.

A discount rate of 12 percent was chosen on the basis of trends listed in Agricultural Statistics 1980. The most recent discount rate listed was 10.18 percent in 1979, which represents the annual interest income on loans, discounts, and notes receivable as a percentage of average balance of such items outstanding during the year (U.S. Department of Agriculture, p. 483). The discount rate of 12 percent was chosen since: (1) the discount rate on investments is expected to be higher than the discount rate on loans and (2) there has been an upward trend in discount rates during the last three years.

For evaluation of alternative fencing strategies, criteria such as labor versus capital requirements, initial investment costs, maintenance costs of different fences during their lifetime, present value calculations, and equivalent level annuities were used.

\section{Sensitivity Analyses}

Sensitivity analyses were conducted to measure the sensitivity of resulting cost figures due to variations in fencing materials costs, labor costs, maintenance costs, years of useful life, and the discount rate. Fencing materials costs were varied because prices change over time and because fencing material sellers and fence construction contractors in different areas have different price lists.

Labor costs and availability change from time to time on individual farms due to family members leaving the farm or accepting off-farm employment. In addition, availability or costs of labor may be different in different locations.

Since fencing specialists who were interviewed provided quite different estimates of maintenance costs, an evaluation of how the results would change with different levels of maintenance costs was necessary. This evaluation, as well as experiments with different years of useful life, was especially necessary for high-tensile fences which are relatively new in the United States.

Finally, experiments with alternative discount rates were performed because farmers probably have different opportunity costs of capital and consequently the choice of any specific discount rate is somewhat arbitrary.

\section{Results}

\section{Fencing Comparisons}

In this section, decision criteria for different fencing strategies using continuous and rotational grazing are presented and discussed. Results then are compared with actual or estimated cost figures of farms in West Virginia and Virginia, where fences have recently been constructed. Budgets of fences used for continuous grazing, rotational grazing, and temporary electric fences used in additional subdivisions are presented in the Appendix.

\section{Comparisons of Three Types of Fences when Continuous Grazing Is Used}

Woven wire fences are more expensive than high-tensile fences, with respect to capital costs, labor costs, and maintenance costs, and they do not last as long as high-tensile fences (Table 1). Investment costs for woven wire fences are more than 120 percent higher than for high-tensile electric fences, and more than 30 percent higher than investment costs of high-tensile nonelectric fences. Average annual maintenance costs of woven wire fencing are about 202 percent higher than electric, and about 255 percent higher than the maintenance costs of nonelectric fencing.

Ten-strand nonelectric fences are more expensive than five-strand electric fences with regard to capital and labor costs, but they last longer and have lower maintenance costs during their lifetime. When continuous grazing is used, investment costs of ten-strand fences are about 70 percent higher than the investment costs of electric fences, but their average annual maintenance costs in terms of dollars are about 15 percent lower than the maintenance costs of electric fencing.

Considering capital/labor ratios, woven wire fences with the ratio of 1.67 are more capital intensive than electric fences with the ratio of 1.47. However, electric fences are more capital intensive than nonelectric fences which have a capital/labor ratio of 1.19 .

Comparing fences in terms of absolute quantities of capital and labor requirements shows that woven wire fences require more capital and more labor than high-tensile fences, and nonelectric fences use more capital and more labor than electric fences. Consequently, the capital/labor ratio is not a useful criterion to use for comparing the different fencing strategies.

Investment costs are incurred when the fences are built, but maintenance costs are incurred during the life of the fences. The present value of the maintenance costs are calculated and are added to the total investment costs to determine present value of maintenance plus investment costs. When the continuous method of grazing is used, the totals of investment and maintenance 
Table 1.

Continuous Grazing: Summary of Decision Criteria for Fencing Strategies Using 25,115 Feet of Permanent Fence and 1981 Retail Price Levels

\begin{tabular}{|c|c|c|c|c|}
\hline \multirow[b]{2}{*}{$\begin{array}{l}\text { Decision } \\
\text { Criteria } \\
\end{array}$} & \multirow[b]{2}{*}{ Units } & \multirow[b]{2}{*}{$\begin{array}{l}\text { Woven } \\
\text { Wire }\end{array}$} & \multicolumn{2}{|c|}{ High Tensile } \\
\hline & & & $\begin{array}{l}\text { Ten-Strand } \\
\text { Nonelectric }\end{array}$ & $\begin{array}{c}\text { Five-Strand } \\
\text { Electric }\end{array}$ \\
\hline $\begin{array}{l}\text { Initial Investment: } \\
\text { Total cash costs } \\
\text { Capital costs } \\
\text { Labor required } \\
\text { Labor costs } \\
\text { Capital as } \% \text { of } \\
\text { total costs } \\
\text { Labor as } \% \text { of } \\
\text { total costs } \\
\text { Capital/Labor ratio } \\
\text { Costs per foot }\end{array}$ & $\begin{array}{c}\$ \\
\$ \\
\text { Hrs. } \\
\$\end{array}$ & $\begin{array}{r}32,898 \\
20,574 \\
2,636 \\
12,323\end{array}$ & $\begin{array}{r}24,676 \\
13,400 \\
2,412 \\
11,276\end{array}$ & $\begin{array}{r}14,525 . \\
8,653 \\
1,256 \\
5,872 \\
\\
60 . \\
\\
40 . \\
1.47 \\
0.58\end{array}$ \\
\hline $\begin{array}{l}\text { Maintenance: } \\
\text { Ave. annual } \% \text { of } \\
\text { total cash costs } \\
\text { Ave. annual costs } \\
\text { Ave. annual costs } \\
\text { per foot }\end{array}$ & $\begin{array}{l}\% \\
\$\end{array}$ & $\begin{array}{c}8.000 \\
2,632 \text {. } \\
0.105\end{array}$ & $\begin{array}{c}3.000 \\
740 . \\
0.029\end{array}$ & $\begin{array}{c}6.000 \\
871 . \\
0.035\end{array}$ \\
\hline $\begin{array}{l}\text { Present Value }(\mathrm{PV}) \text { : } \\
\text { Useful life } \\
\text { PV maintenance } \\
\text { PV maintenance } \\
\text { plus investment }\end{array}$ & $\begin{array}{c}\text { Yrs. } \\
\$\end{array}$ & $\begin{array}{r}20 \\
14,230\end{array}$ & $\begin{array}{r}30 \\
3,189 \\
27,866\end{array}$ & $\begin{array}{r}25 \\
5,024 \\
19,549\end{array}$ \\
\hline $\begin{array}{l}\text { Equivalent } \\
\text { Level Annuity: } \\
\text { Maintenance } \\
\text { Investment } \\
\text { Maintenance plus } \\
\text { investment }\end{array}$ & $\$$ & $\begin{array}{l}1,905 . \\
4,404 .\end{array}$ & $\begin{array}{r}396 . \\
3,063 .\end{array}$ & $\begin{array}{r}641 . \\
1,852 .\end{array}$ \\
\hline
\end{tabular}

costs in present value terms for woven wire, nonelectric, and electric fences are respectively, $\$ 47,128, \$ 27,866$, and $\$ 19,549$.

Since different fences have different economic lives, the net present values of alternative strategies represent investments which are not equivalent in terms of the number of years of use. Therefore, to provide a decision criterion on a more equal basis, equivalent level annuities are used to determine equivalent yearly costs. Equivalent level annuities for maintenance plus investment costs are $\$ 6,309$ for woven wire fences, followed by $\$ 3,459$ for nonelectric, and $\$ 2,493$ for electric fences.

\section{Comparisons of Three Types of Fences when Rotational Grazing Is Used}

When comparisons are made among different fences, the ranking by cost when using rotational grazing is similar to the ranking when continuous grazing was used (Table 2). However, since temporary electric fences used for additional subdivisions require fewer and less expensive materials, the cost per foot figures for all types of fences are less than the comparable figures when continuous grazing is used. Costs per foot of woven wire, nonelectric, and electric fences-each combined with temporary fencing-are $\$ 1.14, \$ 0.87$, and $\$ 0.54$, respectively.

Present value and equivalent level annuity figures are found by adding the corresponding values of permanent fences to temporary electric fences. Equivalent level annuities of investment plus maintenance costs are $\$ 6,782$ for woven wire, $\$ 3,917$ for nonelectric, and $\$ 2,938$ for electric fences, when rotational grazing is considered.

In summary, it can be concluded that woven wire fences are not economical to build, since their investment and maintenance costs are higher than hightensile fences. Moreover, woven wire fences do not last as long.

High-tensile electric fences are cheaper to build than high-tensile nonelectric fences, with respect to both capital and labor costs. However, nonelectric fences need less maintenance and last longer than electric fences. When rotational grazing is used, the maintenance costs for nonelectric fencing are slightly higher than the maintenance costs of electric fencing, since when used with permanent electric fencing, an additional charger is not needed for construction of the temporary fences.

Based on these observations, farmers who have enough capital and have access to sufficient amounts of labor, or farmers who prefer to have fences that last longer and need less maintenance, can consider building high-tensile, nonelectric fences, especially when they are considering the continuous method of grazing. However, farmers who do not have enough capital and/or do not have access to sufficient amounts of labor to build ten-strand nonelectric fencing, may consider electric fences.

\section{Comparisons with Results from Other Situations}

Woven wire and high-tensile fence construction costs information was obtained for fences that have been built in recent years on farms in West 
Table 2.

Rotational Grazing: Summary of Decision Criteria for Fencing Strategies Using 25,115 Feet of Permanent Fence, 5,300 Feet of Temporary Electric Fence, and 1981 Retail Price Levels ${ }^{\mathrm{a}}$

\begin{tabular}{|c|c|c|c|c|}
\hline \multirow[b]{2}{*}{$\begin{array}{l}\text { Decision } \\
\text { Criteria } \\
\end{array}$} & \multirow[b]{2}{*}{ Units } & \multirow[b]{2}{*}{$\begin{array}{c}\text { Woven } \\
\text { Wire }\end{array}$} & \multicolumn{2}{|c|}{ High Tensile } \\
\hline & & & $\begin{array}{l}\text { Ten-Strand } \\
\text { Nonelectric }\end{array}$ & $\begin{array}{c}\text { Five-Strand } \\
\text { Electric }\end{array}$ \\
\hline \multicolumn{5}{|l|}{ Initial Investment: } \\
\hline Total cash costs & $\$$ & 34,734 & 26,513 & 16,298 \\
\hline Capital costs & $\$$ & 21,523 & 14,348 & 9,538 \\
\hline Labor required & Hrs. & 2,826 & 2,602 & 1,446 \\
\hline Labor costs & $\$$ & 13,212 & 12,164 & 6,760 \\
\hline $\begin{array}{l}\text { Capital as } \% \text { of } \\
\text { total costs }\end{array}$ & $\%$ & 62. & 54. & 59. \\
\hline $\begin{array}{l}\text { Labor as } \% \text { of } \\
\text { total costs }\end{array}$ & $\%$ & 38. & 46. & \\
\hline Capital/Labor ratio & & 1.63 & 1.18 & $\begin{array}{r}41 . \\
1.41\end{array}$ \\
\hline Costs per foot & $\$$ & 1.14 & 0.87 & 0.54 \\
\hline \multicolumn{5}{|l|}{$\begin{array}{l}\text { Maintenance: } \\
\text { Ave. annual } \% \text { of }\end{array}$} \\
\hline $\begin{array}{l}\text { Ave. annual } \% \text { of } \\
\text { total cash costs }\end{array}$ & $\%$ & 8.523 & 4.394 & 6.871 \\
\hline $\begin{array}{l}\text { Ave. annual costs } \\
\text { Ave. annual costs }\end{array}$ & $\$$ & 2,960 & 1,165 & 1,120 . \\
\hline per foot & $\$$ & 0.097 & 0.038 & 0.037 \\
\hline \multicolumn{5}{|l|}{ Present Value (PV): } \\
\hline Useful life & Yrs. & 20. & 30. & 25. \\
\hline $\begin{array}{l}\text { PV maintenance } \\
\text { PV maintenance }\end{array}$ & $\$$ & 15,923 & 5,041 & 6,746 \\
\hline plus investment & $\$$ & 50,658 & 31,553 & 23,044 \\
\hline \multicolumn{5}{|l|}{$\begin{array}{l}\text { Equivalent } \\
\text { Level Annuity: }\end{array}$} \\
\hline Maintenance & $\$$ & 2,132 & 626. & 860. \\
\hline $\begin{array}{l}\text { Investment } \\
\text { Maintenance plus }\end{array}$ & $\$$ & 4,650 & 3,291 . & 2,078 \\
\hline investment & $\$$ & 6,782 & 3,917 . & 2,938 \\
\hline
\end{tabular}

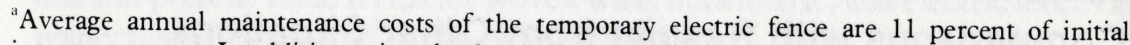
investment costs. In addition, wires, latch-type gates, and parts of the charger are replaced every 7 years.
Virginia. Estimated costs were also obtained from a research farm in Virginia and from a county office of the Agricultural Stabilization and Conservation Service in West Virginia. The actual and estimated cost figures from example farms are compared to the cost figures of this study and the results are summarized in Table 3 and discussed below.

Woven wire, ten-strand nonelectric, and six-strand electric fences were constructed on Frank Woodson's Farm in West Virginia in 1978 (Allegheny Highlands Project). For woven wire fences, the capital costs were $\$ 0.38$ and labor costs $\$ 0.10$ per foot. The respective costs for continuous grazing were $\$ 0.82$ and $\$ 0.49$ in this study. The capital costs of nonelectric fencing were $\$ 0.22$ per foot and labor costs were $\$ 0.09$ per foot, compared to $\$ 0.53$ and $\$ 0.45$ in this research. For electric fencing, the capital and labor costs were respectively $\$ 0.21$ and $\$ 0.08$ compared to $\$ 0.35$ and $\$ 0.23$ in this study.

The actual labor costs of 1978 were lower than the labor costs in this research. The difference can be explained as follows. First, wage rates have risen since 1978. For this research, a wage of $\$ 6.00$ per hour for experienced labor and a wage of $\$ 3.35$ per hour for untrained labor were considered. For Frank Woodson's Farm, wage rates of $\$ 3.00$ and $\$ 4.00$ were used. Second, for Frank Woodson's Farm, 45 percent of the labor needed for construction of woven wire, 43 percent of labor needed for nonelectric, and 42 percent of the labor needed for electric fences was provided by the owners, and no wage rate was considered for their work. In this research, wage rates were considered for all workers. Third, fewer hours of labor for each 1,000 feet of the fence were used in construction of fences in Frank Woodson's Farm than the hours considered in this research. The hours of labor required can vary considerably between farms due to differences in terrain, soil condition, and experience of the labor.

The higher capital costs of this research's results compared to the costs on Woodson's Farm can be due to increases in materials costs since 1978, and possibly different amounts of materials used for construction of fences on that farm, compared to proposed costs for the Willow Bend Farm.

Construction costs of different types of fences were calculated by the Monongalia County Agricultural Stabilization and Conservation Office of West Virginia for cost sharing purposes in 1982. For woven wire fencing, capital and labor costs were $\$ 0.40$ and $\$ 0.15$, respectively, when converted to cost per foot. These respective costs were $\$ 0.31$ and $\$ 0.15$ for high-tensile nonelectric, and $\$ 0.29$ and $\$ 0.09$ for high-tensile electric fencing. Both capital and labor costs are lower than the cost figures of this study. The cost differences may be due to several reasons. First, different amounts of materials and hours of labor might have been used for construction of fences, compared to the proposed cost figures of this study. Second, a wage rate of $\$ 4.00$ per hour was used for labor needed in fence construction compared to $\$ 6.00$ and $\$ 3.35$ per hour used for experienced and inexperienced labor, respectively, in this study. 


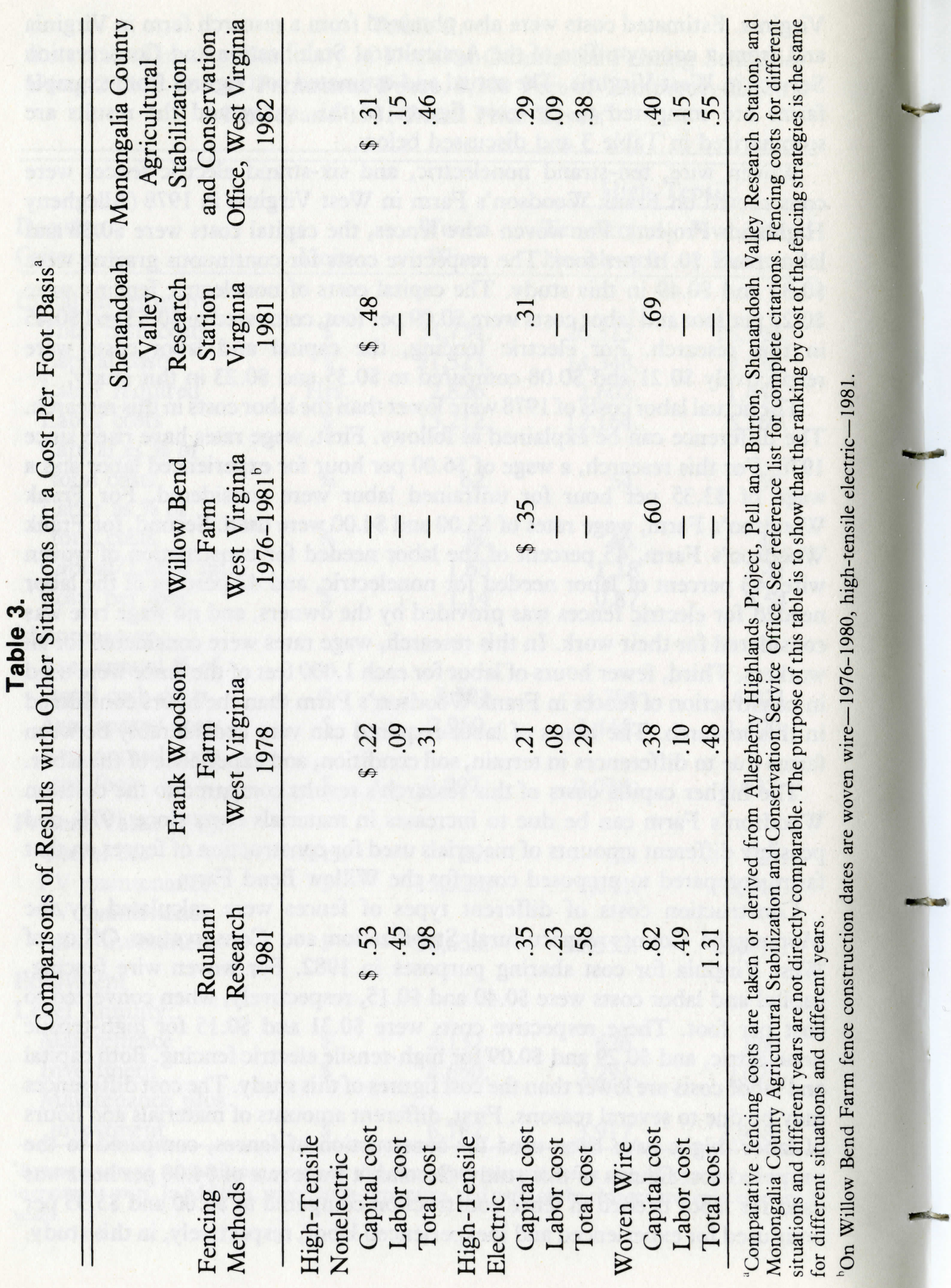

14
Third, the retail prices of materials used for fence construction differ in different stores and different cities.

Estimated capital cost figures of several types of fences are available from the Shenandoah Valley Research Station in Virginia. Based on these estimates capital cost per foot of the woven wire; ten-strand, high-tensile nonelectric; and four-strand, high-tensile electric fences were $\$ 0.69, \$ 0.48$, and $\$ 0.31$, respectively.

On West Virginia University's Willow Bend Farm, the actual capital costs were $\$ 0.60$ and $\$ 0.35$ per foot for woven wire and high-tensile electric fences, respectively (Pell and Burton). No figure was available for high-tensile nonelectric fencing. The cost figures from these sources are lower than the respective costs of this research. This could be due to different amounts of materials used for fence construction and different retail prices. These comparisons show that even though the cost figures are different for different situations, the ranking by costs of the different fencing strategies is consistent with the ranking found in this research.

\section{Discussion}

In this section sensitivity analyses are conducted considering variations in fencing materials costs, labor costs, maintenance costs, years of useful life, and the discount rate. Then, implications of adopting new technology are considered. Finally, policy implications are discussed.

\section{Sensitivity Analyses}

Sensitivity analyses were conducted to determine the magnitude of changes in results in response to variations in costs of capital, labor, and maintenance; in years of useful life; and in the discount rate. Equal percentage changes in costs were applied to each of the fencing strategies. The results are summarized here. Additional numerical details are reported in Rouhani-Iravan (pp. 114-145). Several analyses were also performed to see if hypothetical farm situations could be specified for which the ranking of the fencing strategies would be altered as a result of farmers providing their own inputs.

\section{Capital Costs Variations}

Assuming fixed labor costs, a 10 percent increase in capital costs when the continuous method of grazing is used raised total investment costs of an electric fence by 5.95 percent, nonelectric fence by 5.43 percent, and woven wire fence by 6.25 percent. The same percentage increases are observed if present values or equivalent level annuities are compared with the results presented in Table 1. 
Woven wire fence was more sensitive to capital costs increases than hightensile fences, because a higher percentage of total costs was spent on fencing materials in construction of woven wire fencing. Therefore, it can be concluded that woven wire fences are more sensitive to capital costs variations, followed by electric, and then nonelectric fences.

With further increases in capital costs, the percentage increases in investment costs, present values and equivalent level annuities vary, but the direction of the changes will remain the same and ranking of the fences will not change.

Similar results were observed when capital costs were increased by 10 percent for rotational grazing. The increases in total investment costs were 5.85 percent, 5.41 percent, and 6.20 percent for electric, nonelectric, and woven wire fences, respectively. The results were a little different from those of continuous grazing, because the capital/labor ratios were not the same.

\section{Labor Costs Variations}

To observe changes in decision criteria for fencing strategies due to labor cost changes, capital costs were fixed, and labor costs were assumed to increase by 10 percent. When continuous grazing is considered, the total investment costs of nonelectric fencing increased by 4.57 percent, followed by electric fencing costs which increased by 4.04 percent, and woven wire fencing with a 3.74 percent increase in total investment costs. The results are the same if comparisons are based on percentage increases in present values or equivalent level annuities.

It can be concluded that high-tensile nonelectric fences are more sensitive to labor cost changes, followed by electric and then woven wire fences. This is because of the lower capital/labor ratio used in construction of high-tensile nonelectric fences. With higher increases in labor costs, the direction of changes and the ranking of the fences remain the same, even though the percentage increases in investment costs, present values and equivalent level annuities vary with changes in the rate of labor costs increases.

Similar variations in costs were observed when rotational grazing was used. With a 10 percent increase in labor costs, total investment costs of electric, nonelectric, and woven wire fences increased by $4.18,4.59$, and 3.81 percent, respectively.

Further calculations show that compared with the measured cost of woven wire fencing, total construction costs of high-tensile nonelectric and hightensile electric fencing would have to increase 33 and 126 percent respectively before woven wire fencing can compete with high-tensile fences.

\section{Maintenance Costs Variations}

As the result of a 10 percent decrease in maintenance costs, when continuous grazing is considered, the present values and equivalent level annuities of maintenance plus investment costs decrease by 3.02 percent for woven wire, 2.57 percent for electric, and 1.14 percent for nonelectric fences. Generally, fences are not too sensitive to maintenance costs variations because annual maintenance costs constitute a relatively small percentage of the initial investment costs and because annual maintenance costs are discounted back to the year of the initial investment. However, woven wire fences show more sensitivity than high-tensile fences, since their maintenance costs constitute a greater percentage of the total investment costs.

When the rotational method of grazing is considered, a 10 percent decrease in maintenance costs decreases the total of present values and the total of equivalent level annuities of woven wire fencing by 3.11 percent, electric fencing by 2.82 percent, and nonelectric fencing by 1.52 percent. The direction of changes is similar to that found when analyzing continuous grazing. With decreases in maintenance costs the ranking of the fences is not changed.

Considering continuous grazing, with a 10 percent increase in maintenance costs, the total of present values and the total of the equivalent level annuities increased by $3.02,2.57$, and 1.14 percent for woven wire, electric, and nonelectric fences, respectively.

Considering rotational grazing, the present values and equivalent level annuities of investment plus maintenance costs increased by 3.12 percent for woven wire, 2.85 percent for electric, and 1.58 percent for nonelectric fences.

Conclusions are similar to the case of a 10 percent decrease in maintenance costs: (1) fences are not too sensitive to maintenance costs variations, (2) woven wire fences are more sensitive to maintenance costs variations than high-tensile fences, and (3) the ranking by costs of the fences has not changed with a 10 percent increase in maintenance costs.

Additional sensitivity analysis was conducted to observe if a substantial decrease in the expected life of high-tensile fences can make woven wire fencing more attractive. Assuming both high-tensile electric and nonelectric fences would last only 5 years, the equivalent level annuity of investment plus maintenance costs of woven wire fencing lasting 20 years is still 41 percent higher than the respective average annual cost of electric, but 9 percent lower than the respective average annual cost of nonelectric fencing

\section{Discount Rate Variations}

As a general rule, a decrease in the discount rate will increase the present value of costs, since in the formula $\mathrm{NP}_{0}=\mathrm{Y}_{\mathrm{e}} /(1+\mathrm{r})^{\mathrm{n}}$, a decrease in the discount rate will 
decrease the denominator and consequently the $\mathrm{NP}_{0}$ will increase. ${ }^{4}$

In this study it is assumed that all investment costs are incurred in the initial year when the fence is constructed, so total investment costs are the same as the present value of investment costs. Therefore, changes in the discount rate do not affect the present value of investment costs. Maintenance costs are incurred during the life of the fences, so they are affected by discount rate changes.

Equivalent level annuities of initial investment costs decrease as the result of a decrease in the discount rate. Using the formula $E Q A=N_{0} / E I_{r, n}$, a decrease in the discount rate increases the equivalent level annuity facto $\mathrm{EPIF}_{\mathrm{r}, \mathrm{n}}$, and since the present values of the investment costs have remained the same, the equivalent level annuities decrease..$^{5}$ However, in the case of this study equivalent level annuities of maintenance costs increase with a decrease in the discount rate, since considering the formula $\mathrm{EQA}=\mathrm{NP}_{0} / \mathrm{EPIF}_{\mathrm{r}, \mathrm{n}}$ the increase in the net present value outweighs the increase in the equivalent level annuity factor, and consequently EQA's increase. For the sensitivity analyses, two discount rates, 10 percent and 15 percent, are considered and the results are presented and discussed below.

In the original budgets, a discount rate of 12 percent was used. Considering the continuous method of grazing, and a discount rate of 10 percent (this is a 16.67 percent reduction in the discount rate), the present value of the maintenance costs of electric, nonelectric, and woven wire fences increased by $21.10,29.35$, and 20.00 percent, respectively.

The equivalent level annuities of maintenance costs increase, but the equivalent level annuities of investment costs decrease with a decrease in the discount rates. However, the decrease in the equivalent level annuities of investment costs outweighs the increase in the equivalent level annuities of maintenance costs; consequently, the equivalent level annuities of maintenance plus investment costs decrease.

For electric fencing, a 16.67 percent decrease in the discount rate (from 12 to 10 percent) caused the equivalent level annuity of maintenance costs to increase by 4.52 percent, the equivalent level annuity of investment costs to decrease by 13.61 percent, and the equivalent level annuity of maintenance plus investment costs to decrease by 8.95 percent.

For high-tensile nonelectric fencing, the equivalent level annuity of maintenance costs increased by 9.59 percent, the equivalent level annuity of investment costs decreased by 14.53 percent, and the total of the two equivalent level annuities decreased by 11.68 percent.

${ }^{4} \mathrm{NP}_{0}$ represents the present value, $\mathrm{Y}_{\mathrm{c}}$ represents the equal periodic cash costs associated with the new fencing strategy, $\mathrm{r}$ represents the discount rate, and $\mathrm{n}$ represents the years of useful life. ${ }^{5} \mathrm{EQA}$ represents the equivalent level anuity, and $\mathrm{EPIFr,n}$ represents the equivalent present value interest factor, with a given life expectancy $(\mathrm{n})$.
For woven wire fencing, the equivalent level annuity of maintenance costs increased by 5.30 percent, the equivalent level annuity of investment costs decreased by 12.26 percent, and the total of the two equivalent level annuities decreased by 6.96 percent.

It can be concluded that with a decrease in the discount rate from 12 to 10 percent: (1) the present values of maintenance costs increase, and the equivalent level annuities of investment plus maintenance costs decrease; (2) there are wider variations in the present value and the equivalent level annuity when high-tensile nonelectric fencing is used.

When rotational grazing is considered, similar results are observed. However, the existing differences in percentage increases and decreases are due to the differences in the original budgets for continuous and rotational grazing.

An analysis was also performed with the discount rate increased to 15 percent. The same arguments used for the discount rate of 10 percent are applicable here; however, since the discount rate is increased, all of the changes are in the opposite direction.

With increases in the discount rate, the equivalent total yearly costs of constructing and maintaining the fences increase. This increase in costs is higher for nonelectric fences, since they last longer. The equivalent level annuities of investment plus maintenance costs increased by 18.62 percent for nonelectric fencing as the result of a 25 percent increase in the discount rate (from 12 to 15 percent). This value is higher than the comparable values for electric (14.32 percent), followed by woven wire fencing (11.38 percent). Therefore, with increases in the discount rate the investment in fences becomes less attractive to farmers. This is especially the case with nonelectric fences that have the longest useful life.

Similar results are observed when the rotational method of grazing is considered. However, here the absolute value of the rate of decrease in the present value of maintenance costs of electric fencing is a little lower than the decrease in present value of maintenance costs of woven wire fencing, because an additional charger was not needed in electric fencing when rotational grazing was used.

From the sensitivity analyses it can be concluded that reasonable variations in capital costs, labor costs, maintenance costs, years of useful life, and discount rates do not eliminate the economic advantages of high-tensile fences.

\section{Non Cash Inputs}

Situations could exist in which farmers could provide their own posts and labor to build woven wire fences. They might have to buy higher quality posts and pay for experienced labor for the construction of high-tensile fences. Analyses were also conducted to observe under what circumstances woven wire fencing might cost less than high-tensile fencing. In these analyses the farmer is 
providing some of the inputs at no cost for construction of woven wire fence, but still paying cash for all inputs used in high-tensile fence construction. If we assume that a farmer can do the job of untrained labor and does not consider any wage for his own work, then the cost per foot of woven wire fencing would be $\$ 1.13$ instead of $\$ 1.31$, which is still higher than the respective figures for high-tensile fences. Considering the equivalent level annuities of maintenance plus investment costs, the equivalent level annuity of woven wire fencing is about 58 percent higher than ten-strand and 119 percent higher than fivestrand fencing.

If the farmer builds the whole woven wire fence without hiring any experienced or untrained labor (but hires labor to construct high-tensile fence), the cost per foot of woven wire fence will decrease to $\$ 0.82$, which is lower than the respective cost of ten-strand fencing, but higher than that of five-strand fencing. However, because maintenance cost of woven wire fencing is higher than the maintenance costs of high-tensile fences, the equivalent level annuity of investment plus maintenance costs of woven wire is, respectively, 14 and 58 percent higher than ten-strand and five-strand fences.

If a farmer cuts his own posts for woven wire fencing, the cost per foot of fence will be about $\$ 0.90$, which is higher than the respective cost of electric and lower than that of nonelectric fencing, since posts are purchased for the hightensile fences. However, as with the previous case, the high maintenance cost of woven wire fencing makes its equivalent level annuity of investment plus maintenance higher than high-tensile fences, unless the farmer maintains the fence himself and does not consider any wage for the time he spends on repairs.

If a farmer cuts his own posts and builds the woven wire fence himself without hiring any labor, the cost per foot of the fence will decrease to $\$ 0.41$, which is lower than the respective costs of contracting either electric or nonelectric high-tensile fences, and the equivalent level annuity of maintenance plus investment costs for woven wire will be 42 percent less than nonelectric and 20 percent less than electric fencing.

Thus there may be situations for which woven wire fencing has the lowest cash construction costs because the farmer is able to provide posts and labor inputs. In such cases the farmer might prefer to substitute his own labor for scarce cash. While inputs provided by a farmer have an opportunity value, the opportunity costs of providing posts and labor may be less than the cost of purchasing. Of course, farmers can also provide posts and labor inputs for hightensile fencing, but "fear of the unknown" regarding construction of hightensile fencing may discourage some farmers from providing these inputs.

\section{New Technology}

Since high-tensile fence is a relatively new technology in the United States, farmers may be sensitive to certain costs associated with adoption which are difficult to measure or reflect in an economic analysis.

Most livestock producers who raise both beef and sheep probably know how to construct and maintain woven wire fence. Many lack knowledge about hightensile fences. The time and effort required to obtain and follow the recommendations for correct construction and maintenance of high-tensile fences represent an implicit cost which some farmers may not be willing to pay. There is currently ample knowledge of ways to cut costs when constructing traditional fences; ways to cut costs when using high-tensile fences will be discovered through the experiences of early adopters.

While experience may be described as a "best teacher," "best" in this case may not necessarily imply least cost to individuals who have negative experiences. It is predicted that if increasing numbers of people adopt hightensile fences, the knowledge of correct construction and maintenance will spread and the risk (probability) of individual mistakes will decrease. A large amount of experience over several decades has been expended on traditional fences; those who construct traditional fences today have the opportunity to benefit from these past expenditures. Investments in experience with hightensile fences have only recently started. At this time, it is impossible to objectively measure the long-run maintenance costs of high-tensile fences because there are few high-tensile fences more than 5 years old in the U.S.

In an attempt to obtain a better perspective of the potential adoption costs of high-tensile fencing, we asked several farm managers, agricultural researchers, and extension specialists in West Virginia about the feasibility of high-tensile fencing for livestock producers. We received a wide range of positive and negative opinions regarding high-tensile fences. Some people were concerned about potential problems with anchoring the fence in gullies or low places, maintaining wire tension with changes in moisture or temperature, and driving corner posts deep enough in rocky ground. Failure to follow recommended construction and maintenance practices can result in an ineffective high-tensile fence. The people who are most negative toward high-tensile fences are those who have had the least direct exposure to them or have not carefully followed recommendations for their construction. Many people who have tried hightensile fencing are very positive about it. 


\section{Policy Implications}

This study evaluated fencing strategies for a farm that produces both beef and sheep. Further research is needed to obtain costs estimates of alternative fencing strategies based on actual and varied situations. In particular, additional information is needed about fencing strategies for farms that produce only beef or dairy cattle. In addition, there is potential that hightensile fences may be used to control predators of horticulture crops.

This study also measured the costs of temporary divisional fences which can be used for rotational grazing. Farmers may prefer permanent fences for rotational grazing because of convenience and lower maintenance costs. There is a need for better information about livestock performance and cost efficiency in pasture utilization associated with rotational grazing.

Proponents of high-tensile electric fencing argue that electric fences control predators more effectively than conventional fences. More research is needed to determine the extent to which electric fences more effectively control predators. Based on the potential benefit of predator control and the cost comparisons of this study, it is expected that an increasing number of farmers will adopt electric fencing. If use of electric fences increases, then state and local governments will need to update their fencing laws to clarify the rights and responsibilities of those who use or are affected by electric fencing.

Woven wire fences are more expensive to construct and maintain than hightensile fences; they also do not last as long as high-tensile fences. Therefore, on the basis of an economic perspective, high-tensile fences should be adopted. Compared to traditional fences, however, high-tensile fences require more careful construction and maintenance in order to maintain the tension in the wires necessary to keep them effective and durable. In addition to carefully constructing the fences, farmers who use high-tensile electric fences must take care to ensure that the fence is being charged properly and safely.

Land-grant universities should take a more active role in informing livestock producers about durability, effectiveness, construction requirements, and lower costs of high-tensile fences. Universities may inform livestock producers through publications, extension programs, and demonstrational projects such as those initiated at Willow Bend Farm in West Virginia (Pell and Burton), and at the Shenandoah Valley Research Station in Virginia (McClure). Farmers should be taught to properly construct high-tensile fences or to get help from people who are experienced in high-tensile fence construction.

\section{Conclusion}

Farmers who produce both beef and sheep and who are seeking lower cost fencing will be attracted to high-tensile fencing. Such fences have lower investment and maintenance costs than woven wire fences. Moreover, hightensile fences are expected to last longer.

In terms of both capital and labor costs, high-tensile electric fences are cheaper to build than high-tensile nonelectric fences. Permanent high-tensile nonelectric fences last longer and need less maintenance than permanent electric fences. However, when rotational grazing is used, the maintenance costs for nonelectric fencing are slightly higher than the maintenance costs of electric fencing, since an additional charger, when used with permanent electric fencing, is not needed for construction of the temporary fences.

The results of this research indicate that farmers who produce both beef and sheep and who seek lower cost and less labor intensive fencing will be attracted to high-tensile fencing. Farmers who have enough capital and have access to sufficient amounts of labor, or who prefer to have fences that last longer and need less maintenance, will probably prefer high-tensile nonelectric fences, especially when they are considering the continuous method of grazing. However, farmers who prefer the lowest possible investment costs will likely choose high-tensile electric fences. 


\section{References}

Allegheny Highlands Project. Unpublished Fence Construction Costs Information. West Virginia University, 1978.

Armstrong, R. H., C. H. Banks, and M. P. Gill. A Guide to Electric Fencing. UK: Hill Farming Research Organization, 1981.

Baker, Barton S., Marvin R. Fausett, Paul E. Lewis, and E. Keith Inskeep. A Progress Report on the Allegheny Highlands Project: Agriculture, Fanuary-December 1978. College of Agriculture and Forestry, West Virginia University.

Barr, Alfred L. Beef Cattle Production. West Virginia University Agricultural Experiment Station Bulletin 527, June 1966.

McClure, William H. "Modern Fencing Systems for Virginia (A progress report)," Shenandoah Valley Research Station at Steeles Tavern, Virginia, Not Dated.

Monongalia County Agricultural Stabilization and Conservation Service Office. Unpublished Cost and Cost Share Data, February 1982.

Pell, Edward W. and Robert O. Burton, Jr. Willow Bend Demonstrational Farm: 1981 Annual Report with 1979 and 1980 Livestock and Financial Summaries, West Virginia Agricultural and Forestry Experiment Station, February 1984.

Rouhani-Iravan, Maliheh. "Economics of Alternative Fencing Strategies for Livestock Producers," unpublished M.S. Thesis, West Virginia University,
1982.

Selders, A. W. High-Tensile Wire Fencing. Northeast Regional Agricultural Engineering Service (NRAES-11), June 1980.

Shenandoah Valley Research Station. "Relative Fence Cost Developed for Virginia Fencing Field Day." Steeles Tavern, Virginia, November 5, 1981.

U.S. Department of Agriculture. Agricultural Statistics 1980. Washington, D.C. April 1980.

U.S. Department of Commerce, Bureau of the Census. 1978 Census of Agriculture, Preliminary Report. Washington, D.C. April 1980.

West Virginia Crop Reporting Service, U.S. Department of Agriculture. West Virginia Agricultural Statistics, 1981.

\section{Appendix:}

\section{Fencing Budgets}

In this section, the budgets prepared for different fencing strategies using continuous and rotational methods of grazing are presented. Prices are 1981 retail prices.

Budgets for five-strand electric, ten-strand nonelectric, and woven wire fences when continuous grazing is used are presented in Tables A-1, A-2, and A-3.

For the rotational method of grazing, temporary electric fences are used for additional subdivisions. For each type of fencing, the materials required for construction of the temporary fences are used in combination with the materials needed for the respective type of fence when continuous grazing is used.

The budget for temporary fence used with permanent ten-strand nonelectric fence is presented in Table A-4. Since the wire and gates used with temporary electric fences last about 7 years, necessary periodic reinvestments will be made so that the life expectancy of the temporary fences will terminate at the same time as the permanent fences. Budgets for temporary fences used with the other two fencing strategies are not included because the three temporary fencing budgets are the same with two exceptions: (1) an additional charger is not needed when temporary fences are used with permanent electric fences, and (2) the present values of maintenance costs are different due to the different number of times that reinvestment in temporary fences is made.

Budgets for five-strand electric, ten-strand nonelectric, and woven wire fences-each combined with temporary fencing for rotational grazing-are presented in Tables A-5, A-6, and A-7. 
Table A-1.

Five-Strand, High-Tensile Electric Fence Budget for Continuous Grazing on Willow Bend Farm, 1981 Price Level

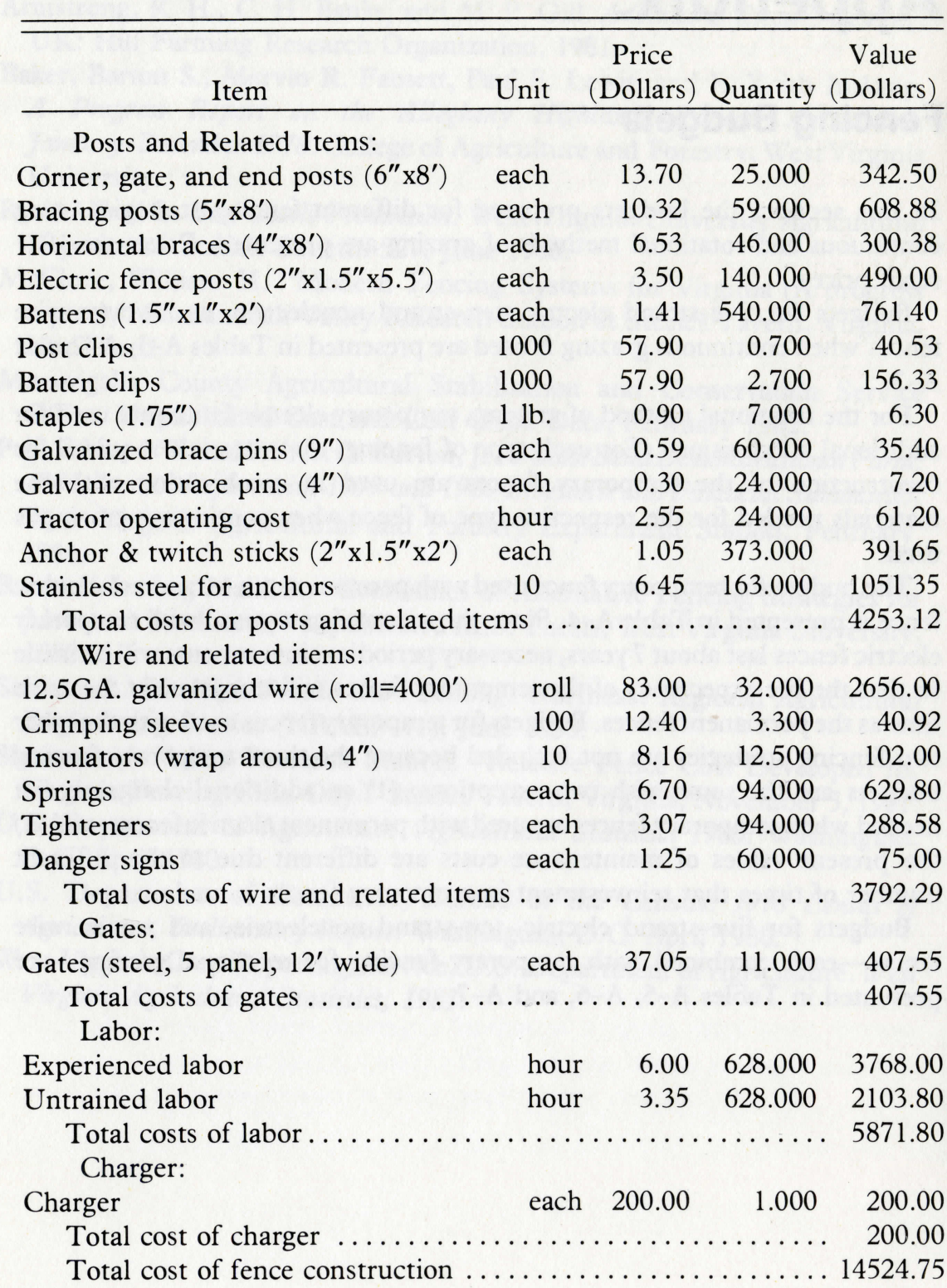

Table A-1. (continued)

Costs of input categories as a percent of total investment costs

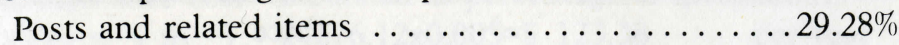

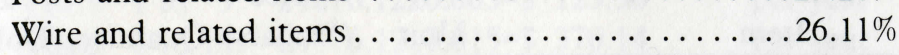

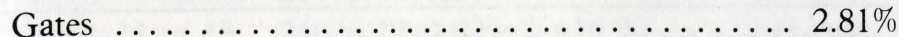

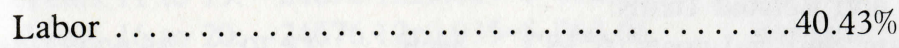

Charger ................................

Cost per foot $\ldots \ldots \ldots \ldots \ldots \ldots \ldots \ldots \ldots \ldots . \$ 0.58$

Maintenance costs calculated as percentage of investment:

Years 1 to $5: 14524.75 \times 0.03=\$ 435.74$ per year

Years 6 to $10: \quad 14524.75 \times 0.04=\$ 580.99$ per year

Years 11 to $15: 14524.75 \times 0.06=\$ 871.48$ per year

Years 16 to 20 : $14524.75 \times 0.08=\$ 1161.98$ per year

Years 21 to $25: \quad 14524.75 \times 0.09=\$ 1307.23$ per year

Average annual maintenance costs are: 6.0 percent.

Present value of maintenance costs . . . . . . . \$5024.37 
Table A-2.

Ten Strand, High-Tensile Nonelectric Fence Budget for Continuous Grazing on Willow Bend Farm, 1981 Price Level

\begin{tabular}{|c|c|c|c|c|}
\hline Item & Unit & $\begin{array}{c}\text { Price } \\
\text { (Dollars) }\end{array}$ & Quantity & $\begin{array}{l}\text { Value } \\
\text { (Dollars) }\end{array}$ \\
\hline \multicolumn{5}{|l|}{ Posts and Related Items: } \\
\hline Corner, gate, and end posts $\left(6^{\prime \prime} \times 8^{\prime}\right)$ & each & 13.70 & 25.000 & 342.50 \\
\hline Bracing posts $\left(5^{\prime \prime} \times 8^{\prime}\right)$ & each & 10.32 & 103.000 & 1062.96 \\
\hline Horizontal braces $\left(4^{\prime \prime} \times 8^{\prime}\right)$ & each & 6.53 & 92.000 & 600.76 \\
\hline Line posts $\left(4^{\prime \prime} \times 6.5-7^{\prime}\right)$ & each & 3.50 & 620.000 & 2170.00 \\
\hline Dip posts $\left(3^{\prime \prime} \times 8^{\prime}\right)$ & each & 4.00 & 165.000 & 660.00 \\
\hline Droppers $\left(1.5^{\prime \prime} \times 1^{\prime \prime} \times 4^{\prime}\right)$ & each & 1.41 & 775.000 & 1092.75 \\
\hline Twitch sticks & each & 1.05 & 92.000 & 96.60 \\
\hline Staples $\left(1.75^{\prime \prime}\right)$ & 50 lb. box & 30.98 & 3.000 & 92.94 \\
\hline Dropper clips & 1000 & 57.90 & 7.750 & 448.72 \\
\hline Galvanized brace pins $\left(9^{\prime \prime}\right)$ & each & 0.59 & 108.000 & 63.72 \\
\hline Galvanized brace pins ( $\left.4^{\prime \prime}\right)$ & each & 0.30 & 24.000 & 7.20 \\
\hline Tractor operating cost & hour & 2.55 & 98.000 & 249.90 \\
\hline \multicolumn{4}{|c|}{$\begin{array}{l}\text { Total costs for posts and related items } \ldots \ldots \ldots \ldots \ldots \ldots \ldots \\
\text { Wire and related items: }\end{array}$} & 6888.04 \\
\hline 12.5GA. galvanized wire $\left(\right.$ roll $\left.=4000^{\prime}\right)$ & roll & 83.00 & 64.000 & 5312.00 \\
\hline Crimping sleeves & 100 & 12.40 & 6.600 & 81.84 \\
\hline Springs & each & 6.70 & 19.000 & 127.30 \\
\hline Tighteners & each & 3.07 & 190.000 & 583.30 \\
\hline \multicolumn{4}{|c|}{$\begin{array}{l}\text { Total costs of wire and related items ..... } \\
\text { Gates: }\end{array}$} & 6104.43 \\
\hline Gates (steel, 5 panel, 12' wide) & each & 37.05 & 11.000 & 407.55 \\
\hline \multicolumn{4}{|c|}{$\begin{array}{l}\text { Total costs of gates } \ldots \ldots \ldots \ldots \ldots \ldots \ldots \ldots \ldots \ldots \ldots \ldots \\
\text { Labor: }\end{array}$} & 407.55 \\
\hline Experienced labor & hour & 6.00 & 1206.000 & 7236.00 \\
\hline Untrained labor & hour & 3.35 & 1206.000 & 4040.10 \\
\hline \multirow{2}{*}{\multicolumn{5}{|c|}{ 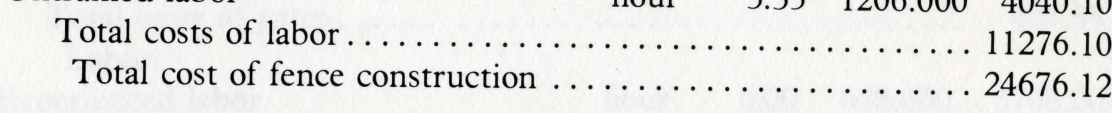 }} \\
\hline & & & & \\
\hline $\begin{array}{l}\text { Costs of input categories as a per } \\
\text { Posts and related items } \ldots \ldots \\
\text { Wire and related items } \ldots \ldots \\
\text { Gates } \ldots \ldots \ldots \ldots \ldots \ldots \ldots \\
\text { Labor } \ldots \ldots \ldots \ldots \ldots \ldots\end{array}$ & $\begin{array}{l}\text { cent of tota } \\
\ldots \ldots \ldots \\
\ldots \ldots \ldots \\
\cdots \cdots \cdots \\
\cdots \cdots \cdots\end{array}$ & $\begin{array}{l}\text { tal investm } \\
\ldots \ldots \ldots \\
\ldots \ldots \ldots \\
\ldots \ldots \ldots\end{array}$ & $\begin{array}{l}\text { ment costs } \\
\ldots 27.91 \% \\
\ldots 24.74 \% \\
\ldots 1.65 \% \\
\ldots 45.70 \%\end{array}$ & \\
\hline Cost per foot ...... & & & & \\
\hline
\end{tabular}

Table A-2. (continued)

Maintenance costs calculated as percentage of investment:

$24676.12 \times 0.005=\$ 123.38$

Years 6 to 10: $24676.12 \times 0.015=\$ 370.14 \quad$ per year

Years 11 to 15 : $24676.12 \times 0.025=\$ 616.90$ per year

Years 16 to $20: 24676.12 \times 0.035=\$ 863.66$ per year

Years 21 to $25: \quad 24676.12 \times 0.045=\$ 1110.43$ per year

Years 26 to 30 : $24676.12 \times 0.055=\$ 1357.19$ per year

Average annual maintenance costs are: 3.0 percent.

Present value of maintenance costs $\ldots \ldots \ldots \ldots \ldots \$ 3189.40$ 
Table A-3.

Woven Wire Fence Budget for Continuous Grazing on Willow Bend Farm, 1981 Price Level

\begin{tabular}{cccc}
\hline \hline & & Price & Value \\
Item & Unit & (Dollars) & Quantity (Dollars) \\
\hline
\end{tabular}

Posts and Related Items:

Corner, gate, and end posts $\left(6^{\prime \prime} \mathrm{x} 8^{\prime}\right) \quad$ each $\quad 13.70 \quad 25.000 \quad 342.50$ Bracing posts $\left(5^{\prime \prime} \mathrm{x} 8^{\prime}\right)$

Horizontal braces $\left(4^{\prime \prime} \mathrm{x} 8^{\prime}\right)$

Line posts $\left(4^{\prime \prime} \mathrm{x} 6.5-7^{\prime}\right)$

Staples $\left(1.75^{\prime \prime}\right)$

Galvanized brace pins $\left(9^{\prime \prime}\right)$

Galvanized brace pins (4")

Tractor operating cost

$\begin{array}{llll}\text { each } & 10.32 & 304.000 & 3137.28\end{array}$

$\begin{array}{llll}\text { each } & 6.53 & 230.000 & 1501.90\end{array}$

$\begin{array}{llll}\text { each } & 3.50 & 1488.000 & 5208.00\end{array}$

\begin{tabular}{lrrr}
$50 \mathrm{lb}$. box $\quad 30.98 \quad 7.000 \quad 216.86$ \\
\hline
\end{tabular}

$\begin{array}{llll}\text { each } & 0.59 & 309.000 & 182.31\end{array}$

$\begin{array}{llll}\text { each } & 0.30 & 24.000 & 7.20\end{array}$

$\begin{array}{llll}\text { hour } & 2.55 & 195.000 & 497.25\end{array}$

Total costs for posts and related items .............. 11093.29 Wire and related items:

$\begin{array}{lllll}\text { Netted } 10 \text { strand wire }\left(\text { roll }=330^{\prime}\right) & \text { roll } & 109.85 & 76.000 & 8348.60\end{array}$

$\begin{array}{llrrr}4 \text { barbed barb wire }\left(\text { roll }=1320^{\prime}\right) & \text { roll } & 27.95 & 20.000 & 559.00\end{array}$

12.5GA. galvanized wire $\left(\right.$ roll $\left.=4000^{\prime}\right) \quad$ roll $83.00 \quad 2.000 \quad 166.00$

Total costs of wire and related items ............... 9073.59 Gates:

Gates (steel, 5 panel, 12' wide) $\quad$ each $\quad 37.05 \quad 11.000 \quad 407.55$ Total costs of gates ........................ 407.55 Labor:

$\begin{array}{lllll}\text { Experienced labor } & \text { hour } & 6.00 & 1318.000 & 7908.00 \\ \text { Untrained labor } & \text { hour } & 3.35 & 1318.000 & 4415.30\end{array}$

hour $\quad 3.35 \quad 1318.000 \quad 4415.30$

Total costs of labo............................. 12323.30

Total cost of fence construction . . . . . . . . . . . . . . . 32897.73

Costs of input categories as a percent of total investment costs

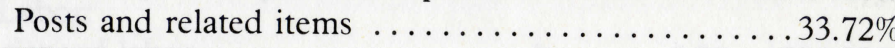

Wire and related items . . . . . . . . . . . . . . 27.58\%

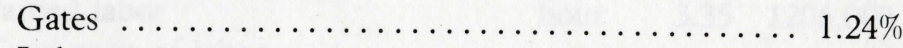

Labor ........................... 37.46\%

Cost per foot $\ldots \ldots \ldots \ldots \ldots \ldots \ldots \ldots \ldots \ldots \$ \ldots 1.31$

Maintenance costs calculated as percentage of investment:

Years 1 to $5: \quad 32897.73 \times 0.03=\$ 986.93$ per year

Years 6 to $10: \quad 32897.73 \times 0.06=\$ 1973.86 \quad$ per year

Years 11 to 15 : $32897.73 \times 0.10=\$ 3289.77$ per year

Years 16 to 20 : $32897.73 \times 0.13=\$ 4276.70 \quad$ per year

Average annual maintenance costs are: 8.0 percent.

Present value of maintenance costs . . . . . . \$14229.89
Table A-4.

Temporary Electric Fence Budget for Rotational Grazing on Willow Bend Farm Used With Ten-Strand, Nonelectric Permanent Fence, 1981 Price Level

\begin{tabular}{cccc}
\hline & & Price & Value \\
Item & Unit & (Dollars) & Quantity (Dollars) \\
\hline
\end{tabular}

Posts and Related Items:

Gates and end posts ( $\left.5^{\prime \prime} \times 8^{\prime}\right)$

Horizontal braces $\left(4^{\prime \prime} \times 8^{\prime}\right)$

Line posts

for temporary $\left(2^{\prime \prime} \times 1.5^{\prime \prime} \times 5.5^{\prime}\right)$

Battens $\left(1.5^{\prime \prime} \times 11^{\prime \prime} \times 2^{\prime}\right)$

Post clips

Batten clips

Anchor \& twitch sticks (2"x1.5"x2')

Stainless steel for anchors

Staples (1.75")

Galvanized brace pins $\left(4^{\prime \prime}\right)$

Tractor operating cost

Total costs for posts and related items ........

Wire and related items:

Tempo. electric fence wire $\left(\right.$ roll $\left.=2640^{\prime}\right)$ roll $33.25 \quad 7.000 \quad 232.75$

$\begin{array}{lllll}\text { Crimping sleeves } & 100 & 12.40 & 0.550 & 6.82\end{array}$

$\begin{array}{lllll}\text { Insulators (wrap around, 4") } & 10 & 8.16 & 2.200 & 17.95\end{array}$

$\begin{array}{lllll}\text { Springs } & \text { each } & 6.70 & 4.000 & 26.80\end{array}$

$\begin{array}{lllll}\text { Tighteners } & \text { each } & 3.07 & 4.000 & 12.28\end{array}$

Total costs of wire and related items ............... 296.60

Gates:

Gate handle with attached spring \& hook each $\quad \begin{array}{lll}1.15 & 5.000 \quad 5.75\end{array}$

Total costs of gates ....................... 5.75

Labor:

$\begin{array}{lllll}\text { Experienced labor } & \text { hour } & 6.00 & 95.000 & 570.00\end{array}$

$\begin{array}{lllll}\text { Untrained labor } \quad \text { hour } & 3.35 & 95.000 & 318.25\end{array}$

Total costs of labor ..................... 888.25

\section{(continued)}


Table A-5.

Combination of Permanent Five-Strand, High-Tensile Electric and Temporary Electric Fence Budget for Rotational Grazing on Willow Bend Farm, 1981 Price Level

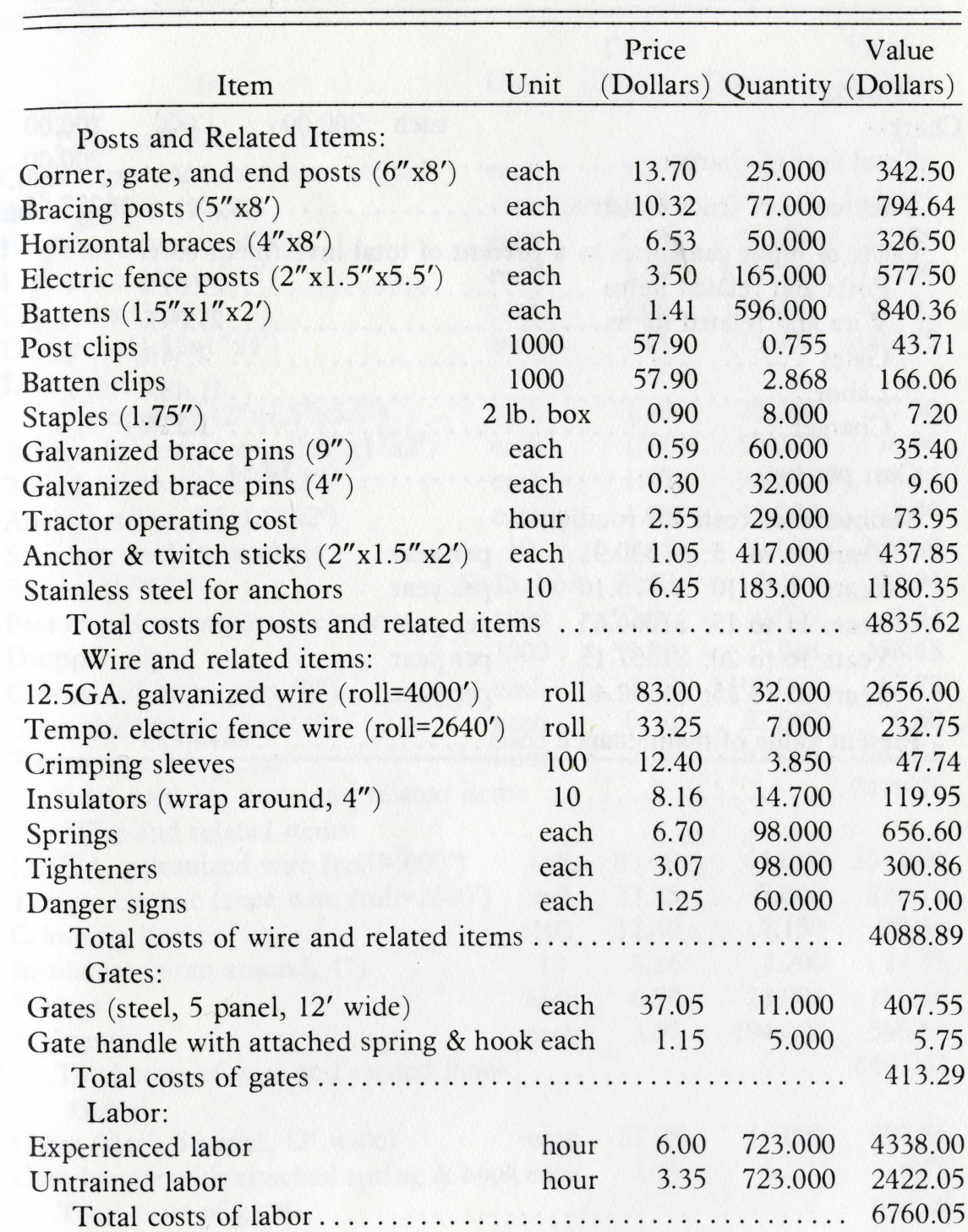

\section{(continued)}




\section{Table A-5. (continued)}

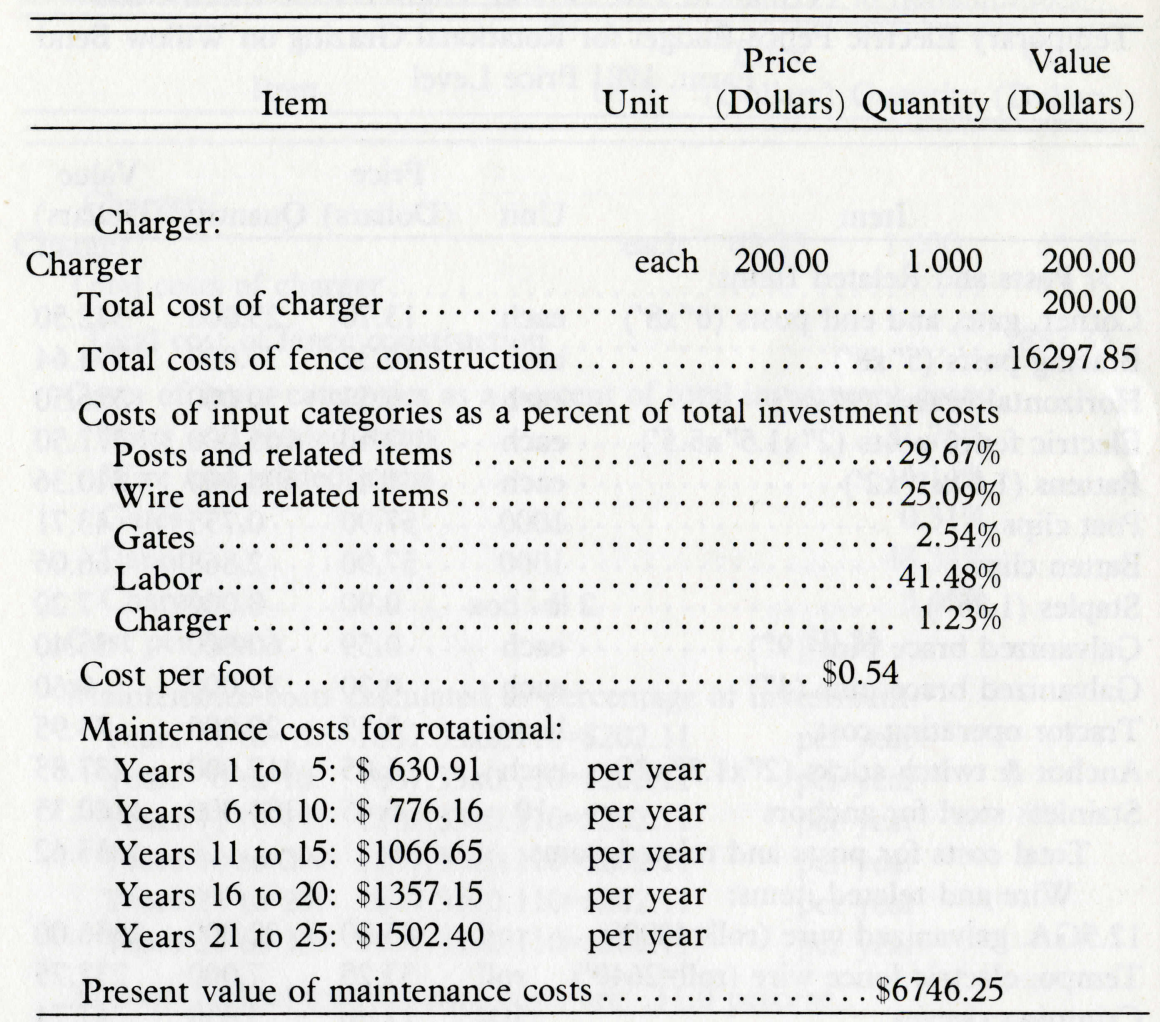

Table A-6.

Combination of Permanent Ten-Strand, High-Tensile Nonelectric and Temporary Electric Fence Budget for Rotational Grazing on Willow Bend Farm, 1981 Price Level

\begin{tabular}{|c|c|c|c|}
\hline Item & Unit & $\begin{array}{c}\text { Price } \\
\text { (Dollars) }\end{array}$ & $\begin{array}{c}\text { Value } \\
\text { Quantity (Dollars) }\end{array}$ \\
\hline
\end{tabular}

Posts and Related Items:

$\begin{array}{llrrr}\text { Corner, gate, and end posts }\left(6^{\prime \prime} \times 8^{\prime}\right) & \text { each } & 13.70 & 25.000 & 342.50 \\ \text { Bracing posts }\left(5^{\prime \prime} \mathrm{x} 8^{\prime}\right) & \text { each } & 10.32 & 121.000 & 1248.72 \\ \text { Horizontal braces }\left(4^{\prime \prime} \times 8^{\prime}\right) & \text { each } & 6.53 & 96.000 & 626.88 \\ \text { Line posts }\left(4^{\prime \prime} \times 6.5-7^{\prime}\right) & \text { each } & 3.50 & 620.000 & 2170.00 \\ \text { Dip posts }\left(3^{\prime \prime} \times 8^{\prime}\right) & \text { each } & 4.00 & 165.000 & 660.00 \\ \text { Droppers }\left(1.5^{\prime \prime} \times 11^{\prime \prime} \times 4^{\prime}\right) & \text { each } & 1.41 & 775.000 & 1092.75\end{array}$

Droppers $\left(1.5^{\prime \prime} \times 1^{\prime \prime} \times 4^{\prime}\right.$

Line posts

for temporary $\left(2^{\prime \prime} \times 1.5^{\prime \prime} \times 5.5^{\prime}\right)$

Battens for temporary $\left(1.5^{\prime \prime} \times 1^{\prime \prime} \times 2^{\prime}\right)$

Twitch sticks $\left(2^{\prime \prime} \times 1.5^{\prime \prime} \times 2^{\prime}\right)$

Anchor stakes (2"x1.5" $\left.\mathrm{x} 2^{\prime}\right)$

Stainless steel for anchors

Staples (1.75")

Post clips for temporary electric

Dropper clips

Galvanized brace pins ( $\left.9^{\prime \prime}\right)$

Galvanized brace pins (4")

Tractor operating cost

each

$\begin{array}{llll}\text { each } & 3.50 & 25.000 & 87.50\end{array}$

$\begin{array}{llll}\text { each } & 1.41 & 56.000 & 78.96\end{array}$

$\begin{array}{lllr}\text { each } & 1.05 & 96.000 & 100.80\end{array}$

$\begin{array}{lllr}\text { each } & 1.05 & 40.000 & 42.00\end{array}$

$\begin{array}{llll}10 & 6.45 & 20.000 & 129.00\end{array}$

50 lb. box $\quad 30.98 \quad 3.000 \quad 92.94$

$\begin{array}{llll}1000 & 57.90 & 0.075 & 4.34\end{array}$

$\begin{array}{llll}1000 & 57.90 & 7.918 & 458.45\end{array}$

$\begin{array}{lrrr}1000 & 57.90 & 7.918 & 458.45 \\ \text { each } & 0.59 & 108.000 & 63.72\end{array}$

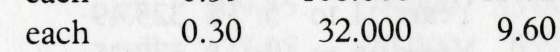

$\begin{array}{lll}\text { hour } & 2.55 \quad 103.000 \quad 262.65\end{array}$

Total costs for posts and related items ............. 7470.79

Wire and related items:

12.5GA. galvanized wire $\left(\right.$ roll $\left.=4000^{\prime}\right) \quad$ roll $\quad 83.00 \quad 64.000 \quad 5312.00$

Tempo. electric fence wire $\left(\right.$ roll $\left.=2640^{\prime}\right)$ roll $33.25 \quad 7.000 \quad 232.75$

$\begin{array}{lllll}\text { Crimping sleeves } & 100 & 12.40 & 7.150 & 88.66\end{array}$

$\begin{array}{llrrr}\text { Insulators (wrap around, 4") } & 10 & 8.16 & 2.200 & 17.95\end{array}$

$\begin{array}{lllll}\text { Springs } & \text { each } & 6.70 & 23.000 & 154.10\end{array}$

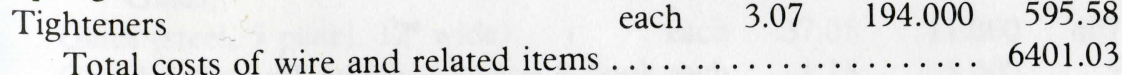

Gates: $\quad$.

$\begin{array}{lrrrr}\text { Gates (steel, 5 panel, 12' wide) each } & 37.05 & 11.000 & 407.55 \\ \end{array}$

Gate handle with attached spring \& hook each $\quad \begin{array}{lll}1.15 & 5.000 & 5.75\end{array}$

Total costs of gates $\ldots \ldots \ldots \ldots \ldots \ldots \ldots \ldots \ldots \ldots \ldots \ldots \ldots \ldots \ldots \ldots \ldots \ldots$

\section{(continued)}


Table A-6. (continued)

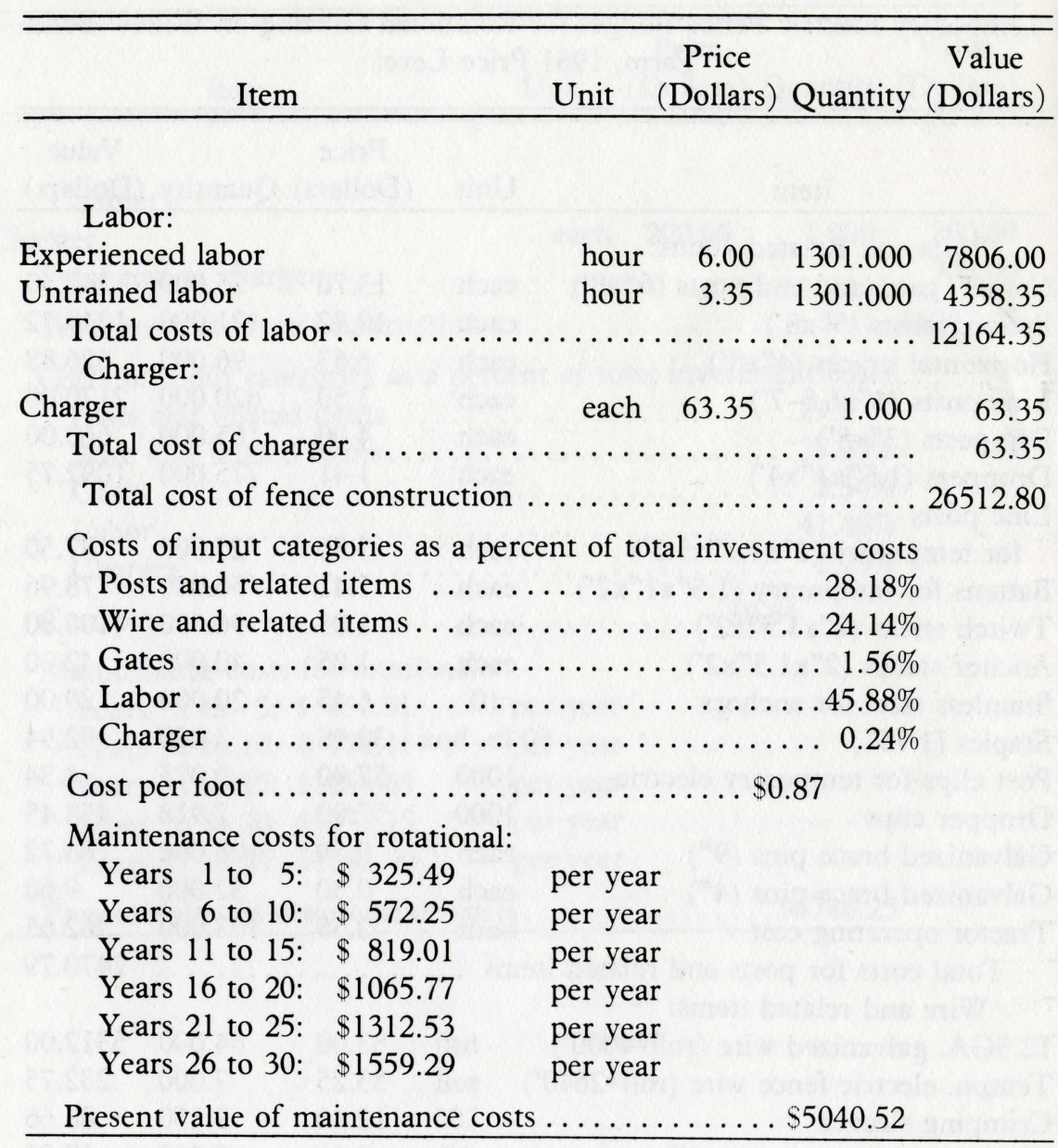

Table A-7.

Combination of Permanent Woven Wire and Temporary Electric Fence Budget for Rotational Grazing on Willow Bend Farm, 1981 Price Level

\begin{tabular}{cccc}
\hline & Price & Value \\
Item & Unit & (Dollars) Quantity (Dollars) \\
\hline
\end{tabular}

Posts and Related Items:

Corner, gate, and end posts $\left(6^{\prime \prime} \times 8^{\prime}\right)$

Bracing posts $\left(5^{\prime \prime} \times 8^{\prime}\right)$

Horizontal braces $\left(4^{\prime \prime} \times 8^{\prime}\right)$

Line posts $\left(4^{\prime \prime} \times 6.5-7^{\prime}\right)$

Line posts

for temporary $\left(2^{\prime \prime} \times 1.5^{\prime \prime} \times 5.5^{\prime}\right)$

Battens (1.5" $\left.\times 11^{\prime \prime} \times 2^{\prime}\right)$

Post clips

Batten Clips

Anchor \& twitch sticks (2"x1.5"x2')

Stainless steel for anchors

Staples (1.75")

Galvanized brace pins $\left(9^{\prime \prime}\right)$

Galvanized brace pins ( $\left.4^{\prime \prime}\right)$

Tractor operating cost

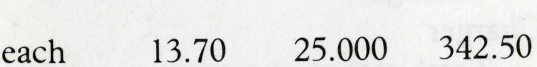

Total costs for posts and related iten

$\begin{array}{rrrr}\text { each } & 10.32 & 322.000 & 3323.04 \\ \text { each } & 6.53 & 234.000 & 1528.02 \\ \text { each } & 3.50 & 1488.000 & 5208.00\end{array}$

Wire and related items:

Netted 10 strand wire $\left(\right.$ roll $\left.=330^{\prime}\right) \quad$ roll $\quad 109.85 \quad 76.000 \quad 8348.60$

4 barbed barb wire (roll $\left.=1320^{\prime}\right)$

12.5GA. galvanized wire (roll $=4000^{\prime}$ )

Tempo. electric fence wire (roll $=2640^{\prime}$ )

Crimping sleeves

Insulators (wrap around, 4"

Springs

$3.50-25.000+87.50$

$\begin{array}{llll}\text { each } & 1.41 & 56.000 & 78.96\end{array}$

$\begin{array}{llll}1000 & 57.90 & 0.075 & 4.34\end{array}$

$\begin{array}{llll}1000 & 57.90 & 0.075 & 4.34 \\ 1000 & 57.90 & 0.168 & 9.73\end{array}$

$\begin{array}{llll}\text { each } & 1.05 & 44.000 & 46.20\end{array}$

$\begin{array}{llll}10 & 6.45 & 20.000 & 129.00\end{array}$

$\begin{array}{llll}50 \text { lb. box } \quad 30.98 \quad 7.000 & 216.86\end{array}$

$\begin{array}{llll}\text { each } & 0.59 & 309.000 & 182.31\end{array}$

$\begin{array}{llll}\text { each } & 0.30 & 32.000 & 9.60\end{array}$

$\begin{array}{llll}\text { hour } & 2.55 \quad 200.000 \quad 510.00\end{array}$

ms

Tighteners

$\begin{array}{lrrr}\text { roll } & 109.85 & 76.000 & 8348.60 \\ \text { roll } & 27.95 & 20.000 & 559.00\end{array}$

$\begin{array}{llrl}\text { roll } \quad 83.00 \quad 2.000 & 166.00\end{array}$

$\begin{array}{llll}\text { roll } \quad 33.25 & 7.000 & 232.75\end{array}$

$\begin{array}{lllr}100 & 12.40 & 0.550 & 6.82\end{array}$

$\begin{array}{llll}10 & 8.16 & 2.200 & 17.95\end{array}$

$\begin{array}{llll}\text { each } & 6.70 & 4.000 & 26.80\end{array}$

$\begin{array}{llll}\text { each } & 3.07 & 4.000 & 12.28\end{array}$

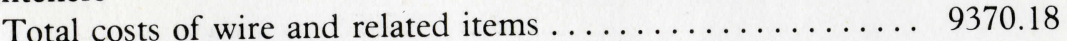
Gates:

Gates (steel, 5 panel, 12' wide) $\quad$ each $\quad 37.05 \quad 11.000 \quad 407.55$

Gate handle with attached spring \& hook each $\quad \begin{array}{lll}1.15 & 5.000 & 5.75\end{array}$

Total costs of gates ..................... 413.29 Labor:

Experienced labor

hour $\quad \begin{array}{llll}6.00 & 1413.000 \quad 8478.00\end{array}$

Untrained labor

$\begin{array}{llll}\text { hour } & 3.35 & 1413.000 & 4733.55\end{array}$

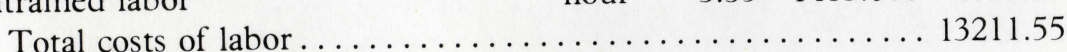

\section{(continued)}


Table A-7. (continued)

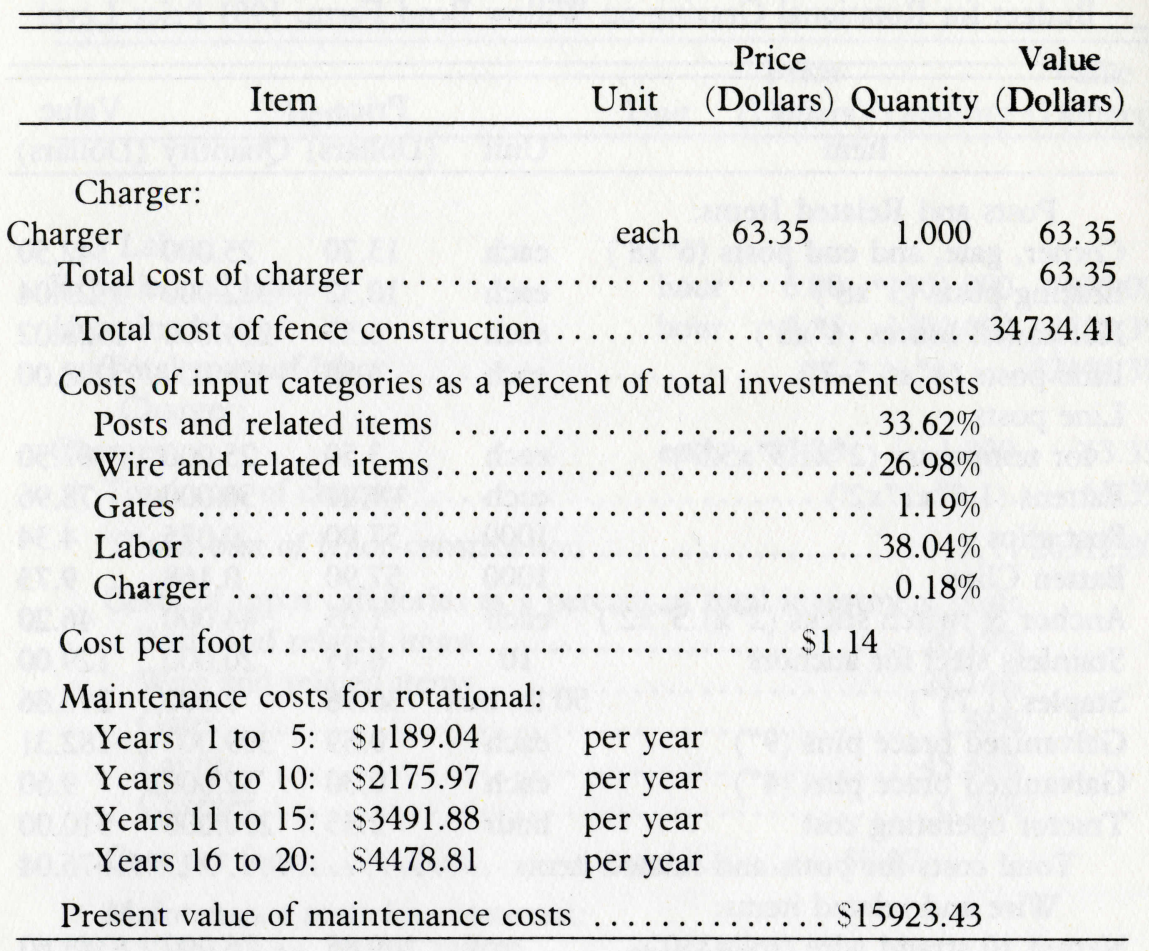

